\title{
Pengaturan Tindak Pidana Zina Dalam KUHP Dikaji Dari Perspektif Living Law
}

\author{
Sahran Hadziq \\ Program Pascasarjana Fakultas Hukum Universitas Islam Indonesia \\ Jl. Cik Di Tiro No. 1, Yogyakarta, 55223 \\ alanhadziq@gmail.com
}

\begin{abstract}
The regulation of adultery in the Indonesian legal system has several elements that are incompatible with the meaning of adultery in living law in the society. Article 284 of the Indonesian Criminal Code (KUHP) prohibits sexual intercourse by a couple outside the wedlock or the forbidden sexual relations. However, one element in this Article stipulates that sexual relations are only prohibited and may be subjected to the Article only if one of the offenders is married. Therefore, according to these elements, it is natural for the public to interpret that infidelity cannot be considered as adultery. Using a socio-legal and historical approach, this study aims to examine the regulation of criminal acts of adultery both in the Criminal Code and from the perspective of the law that lives in the society, which has a discrepancy between one another. The results show that there are many discrepancies or ineffectiveness between the applicable regulation and the reality in the society. These discrepancies are also found in the elements of such applicable law, which results in the inability to apply the adultery article in the community. Therefore, there must be an effective and efficient form of adultery regulations in Indonesia that are in line with the law that lives in the society.
\end{abstract}

Keywords: Adultery; criminal law policy; governance; living law

\begin{abstract}
Abstrak
Pengaturan tindak pidana perzinaan dalam sistem hukum Indonesia memiliki beberapa unsur yang tidak sesuai dengan makna perzinaan dalam living law di masyarakat. Pasal 284 Kitab Undang-Undang Hukum Pidana (KUHP) melarang hubungan seksual yang dilakukan oleh pasangan tanpa ikatan perkawinan atau hubungan seksual yang dilarang. Akan tetapi, salah satu unsur dalam Pasal ini menetapkan bahwa hubungan seksual hanya dilarang dan dapat dikenakan Pasal ketika salah satu pelaku sudah menikah. Oleh karena itu, menurut unsur tersebut, wajar jika masyarakat umum memaknai bahwa perselingkuhan tidak bisa dianggap sebagai perzinaan. Dengan menggunakan pendekatan sosio-hukum dan historis, penelitian ini bertujuan untuk mengkaji pengaturan tentang tindak pidana perzinaan baik dalam KUHP maupun dari perspektif hukum yang hidup di masyarakat, yang memiliki ketidaksesuaian antara satu dengan yang lain. Hasil penelitian menyimpulkan bahwa ada banyak ketidaksesuaian atau ketidakefektifan dalam peraturan yang berlaku dengan kenyataannya di masyarakat. Ketidaksesuaian tersebut juga ditemukan dalam unsur-unsur hukum yang berlaku sehingga menyebabkan tidak dapat diterapkannya pasal perzinaan di masyarakat. Oleh karena itu, harus ada perumusan peraturan perzinaan yang efektif dan efisien di Indonesia yang sejalan dengan hukum yang hidup di masyarakat.
\end{abstract}

Kata-kata Kunci : Kebijakan hukum pidana; living law; pengaturan; zina 


\section{Pendahuluan}

Zina merupakan perbuatan hubungan intim yang dilakukan oleh dua pasang manusia yang tidak memiliki hubungan perkawinan sebelumnya. Zina termasuk salah satu perbuatan yang tidak boleh dilakukan oleh setiap manusia dengan alasan apa pun. Setiap aspek di dalam kehidupan baik dari aspek agama, budaya maupun sosial menyatakan bahwa zina merupakan perbuatan yang tidak pantas untuk dilakukan oleh manusia.

Zina secara etimologis berasal dari bahasa Arab yang artinya persetubuhan di luar pernikahan. ${ }^{1}$ Pengertian zina secara umum adalah persetubuhan priawanita tanpa ikatan perkawinan yang sah. Dari segi tata susila perbuatan ini sangat kotor, hina dan tercela dalam pandangan masyarakat, sedangkan dari segi agama perbuatan ini terhukum dosa. Tidak ada yang mengingkari dalam memberikan hukuman kecuali mereka yang pikirannya beda di bawah kendali hawa nafsunya. Mereka menganggap setiap pelanggaran hukum dan peraturan adalah suatu ciptaan baru hasil falsafah hidup manusia. ${ }^{2}$

Kehidupan yang ada saat ini telah mengatur terkait dengan perbuatan zina. Pengaturan tersebut dilakukan oleh setiap aspek yang ada di dalam kehidupan. Aspek yang dominan dalam mengatur terkait dengan perbuatan zina ada tiga aspek antara lain aspek agama, aspek budaya atau adat istiadat dan aspek hukum. Setiap aspek tersebut memiliki kesamaan terkait dengan pernyataan bahwa zina merupakan perbuatan yang menyalahi kodrat manusia dan tidak boleh dilakukan oleh setiap manusia. Hal ini memberikan gambaran bahwa setiap aspek di dalam kehidupan tidak ada yang membenarkan perbuatan zina, maka dari itu sudah selayaknya bagi manusia untuk menjauhkan perbuatan zina dalam kehidupan.

Pengaturan zina di dalam aspek agama berpedoman dari aturan yang diberikan oleh Tuhan dalam kitab suci masing-masing agama. Termasuk Agama Islam sebagai agama mayoritas yang ada di Indonesia, memiliki pengaturan zina di dalam kitab suci Al-Qur'an dan juga As-Sunnah. Zina di dalam Agama Islam telah diatur terkait dengan larangan maupun hukumannya. Dalam agama Islam

1 Erman Sulaeman, Delik Perzinaan Dalam Pembaharuan Hukum Pidana di Indonesia, Walisongo Press, Semarang, 2008, hlm. 47.

2 Abdul A’la Almaududi, Kejamkah Hukum Islam, Gema Insani Press, Jakarta, 1979, hlm. 36-37. 
hal ini disebut sebagai hukum Islam atau syari'at Islam yang memiliki kekuatan mengikat bagi umat beragama Islam.

Hukuman bagi pelaku zina yang belum menikah (ghoiru muhsan) didasarkan pada ayat Al-Qur'an Surat An-Nuur ayat 2, yang artinya:

“Pezina perempuan dan pezina laki-laki deralah mereka masing-masing seratus kali, dan dalam menjalankan ketentuan Allah jangan kamu digoda rasa kasihan kalau betul-betul kamu beriman kepada Allah dan hari yang akhir. Hendaknya ada kelompok yang mengawasi pelaksanaan hukuman yang terdiri dari orang-orang beriman". ${ }^{3}$

Bagi orang yang sudah menikah (muhsan) hukumannya menurut para ahli hukum Islam adalah rajam (dilempari batu) sampai mati. Hukuman ini disandarkan pada Hadits Nabi SAW yang diriwayatkan oleh Muslim dari ‘Ubadah bin Shamit, yang artinya:

"Dari Ubadah Ibn ash-Shamit ia berkata Rasulullah Bersabda: ambillah dari diriku, ambillah dari diriku, sesungguhnya Allah telah memberi jalan keluar (hukuman) untuk mereka (pezina). Jejaka dan perawan yang berzina hukumannya dera seratus kali dan pengasingan selama satu tahun. Sedangkan duda dan janda hukumannya dera seratus kali dan rajam". ${ }^{4}$

Zina dapat dibuktikan baik dengan pengakuan maupun dengan persaksian. Dalam hal terdapat pengakuan, menurut Syafi'i dan Malik, bila pelakunya dewasa dan berakal yang mengakui perbuatannya itu, maka hukuman harus dijatuhkan. Abu Hanifah, Ahmad, dan Syiah Imamiah berpendapat bahwa hukuman tidak dijatuhkan, kecuali pengakuan pelaku diulang-ulang sebanyak empat kali. ${ }^{5}$

Sesuatu yang menarik dalam eksekusi hukuman rajam atas pelaku zina muhsan adalah apabila pembuktian didasarkan pada pengakuannya sendiri. Apabila ia kemudian melarikan diri pada saat hukuman dijatuhkan, menurut mayoritas ahli hukum, tidak perlu dikejar. ${ }^{6}$

\footnotetext{
${ }^{3}$ Zaini Dahlan, Qur'an Karim dan Terjemahan Artinya, Cetakan kesembilan, UII Press, Yogyakarta, 2010, hlm. 619.

${ }^{4}$ Imam Abi Husein Muslim bin Hajjaj Al-Qusaery an-Nasaburi, Shabih Muslim Juz II, Dar Kitab Al-Ilmiyah, Beirut, 1996, hlm. 48.

5 Topo Santoso, Membumikan Hukum Pidana Islam: Penegakan Syariat dalam Wacana dan Agenda, Cetakan Pertama, Gema Insani Press, Jakarta, 2003, hlm. 124.

${ }^{6} \mathrm{Ibid}, \mathrm{hlm} .125$.
} 
Pengaturan zina di dalam aspek budaya atau adat istiadat tidak bisa lepas dari masyarakat hukum adat. Masyarakat hukum adat adalah komunitas (paguyuban) sosial manusia yang merasa bersatu karena terikat oleh kesamaan leluhur dan atau wilayah tertentu, memiliki kekayaan sendiri, dipimpin oleh seorang atau beberapa orang yang dipandang memiliki kewibawaan atau kekuasaan, atau memiliki tata nilai sebagai pedoman hidup, serta tidak mempunyai keinginan untuk memisahkan diri. ${ }^{7}$

Pengaturan terkait zina dalam hukum adat termasuk di dalam bagian delik adat. Menurut Bushar Muhammad bahwa delik adat adalah setiap perbuatan sepihak dari sepihak atau kumpulan perorangan, mengancam atau menyinggung atau mengganggu keseimbangan dalam kehidupan persekutuan, bersifat materiil atau immateriil, terhadap orang seorang atau terhadap masyarakat berupa kesatuan, tindakan atau perbuatan yang demikian mengakibatkan suatu reaksi adat yang dipercayainya dapat memulihkan keseimbangan yang telah terganggu, antara lain dengan berbagai jalan dan cara, dengan pembayaran adat berupa barang, uang, mengadakan selamatan, memotong hewan besar/kecil dan lain-lain. ${ }^{8}$

Pengaturan zina di dalam aspek hukum sangat jelas terlihat, termasuk di dalam hukum Indonesia. Terkait dengan pengaturan zina dalam hukum Indonesia tidak bisa lepas dari sistem hukum yang ada di Indonesia. Sistem hukum Indonesia atau bisa disebut dengan sistem yuridis Tata Hukum Indonesia berdasar pada Undang-Undang Dasar 1945 sehingga dapat diartikan sebagai berikut:9 paling tinggi dan paling menentukan adalah "hukum tidak tertulis" yang disebut "suasana kebatinan," atau "semangat" atau "rechtsidee." Secara pokok hal ini terdapat di dalam Pembukaan Undang-Undang Dasar 1945 dan dijelaskan pada bagian Umum dari Penjelasan Undang-Undang 1945. Oleh Penjelasan UndangUndang dasar 1945 hal ini dinamakan sebagai "Hukum Dasar yang Tidak Tertulis" atau dengan istilah asing disebut "Droit Constituionel". Di samping rechtsidee ini ada Undang-Undang dasar yaitu suatu jenis "Hukum Tertulis" dalam suatu tingkat yang tertinggi sebagai bagian dari hukum dasar yang oleh penjelasan disebut

\footnotetext{
${ }^{7}$ Rosdalina, Hukum Adat, Cetakan Pertama, Deepublish, Yogyakarta, 2017, hlm. 113.

${ }^{8}$ Muhammad Bushar, Asas-Asas Hukum Adat Suatu Pengantar, Pradnya Paramita, Jakarta, 2006, hlm. 61-62.

${ }_{9}^{9}$ Mudzakkir, Selayang Pandang Sistem Hukum Indonesia Menurut H. Moh. Koesnoe, Universitas Indonesia, Jakarta, 1997, hlm. 19.
} 
dengan istilah asing "Loi Constituionelle" yang isinya adalah instruksi kepada Pemerintah Pusat dan lain-lain penyelenggara negara. Di dalam hukum dasar yang tertulis ini terdapat ketentuan-ketentuan dan dasar-dasar untuk dibentuk peraturan pelaksanaan instruksi-instruksi tersebut yang disebut undang-undang.

Pada dasarnya sistem hukum yang ada di Indonesia juga mengatur terkait dengan masalah perzinaan. Hukum perzinaan di Indonesia memiliki polemik sendiri dari ketentuan hingga penerapan sanksi. Bagaimana tidak, hukum yang mengatur perzinaan dalam Kitab Undang-Undang Hukum Pidana (KUHP) dianggap tidak relevan untuk diterapkan dalam masyarakat Indonesia, terutama perzinaan di Indonesia dianggap sebagai tindakan yang sangat tidak pantas dan bertentangan dengan moral dan norma dalam masyarakat yang berbudaya. Pengaturan tentang zina terdapat dalam Pasal 284 KUHP.

Pengaturan perzinaan dan sanksi sangat jelas bahwa Pasal 284 KUHP hanya mengatur masalah perselingkuhan, yang di mana pasal tersebut hanya berlaku jika salah satu pelaku atau keduanya masih terikat oleh perkawinan sah dengan orang lain. Kemudian pada ayat (2) menjelaskan zina merupakan pelanggaran pengaduan, yang hanya bisa dituntut jika pasangan sah melakukan keberatan atau aduan. Sedangkan untuk kasus hubungan seksual di luar konteks pasal ini, akan berlaku asas legalitas, seperti dalam kasus salah satu selebritas di Indonesia tahun 2010, di mana pelaku hanya dituntut berdasarkan Pasal 4 UU Pornografi, Pasal 27 UU Teknologi Informasi dan Pasal 282 KUHP. Ini terjadi karena video aksi para pelaku yang tersebar di dunia maya, jadi jika video itu tidak ada, maka pelakunya tidak terjerat dalam pasal mana pun, karena Pasal 284 KUHP tidak berlaku padanya. Ketentuan itu menimbulkan masalah di masyarakat.

Pandangan publik tentang perzinaan jauh lebih kompleks daripada yang ditetapkan dalam hukum nasional. Perzinaan bukan hanya selingkuh, tetapi lebih bermoral dan harus dicegah sejak dini, dan bukan hanya setelah menikah. Perspektif ini muncul dalam masyarakat karena pengaruh norma-norma agama dan kekuasaan yang kuat dari rakyat terhadap nilai-nilai Pancasila, di mana ajaranajaran pertama menyebutkan "Kepercayaan pada Yang Maha Agung" sehingga hukum yang taat kepada Tuhan lebih baik daripada hukum lainnya. Dengan 
demikian definisi perzinaan yang tertanam dalam nilai-nilai masyarakat cenderung sifat perzinaan dalam agama, yang menganggap perzinaan sebagai tindakan keji, sebagaimana tercantum dalam Al-Quran Surat Al-Isra 'ayat 32, Allah SWT mengatakan "Dan jangan lah kamu mendekati zina, sesungguhnya, zina adalah tindakan yang keji. Dan jalan yang buruk."10

Penjelasan terkait pengaturan zina dalam KUHP di atas memberikan gambaran bahwasanya masyarakat lebih cenderung terhadap pengaturan di dalam hukum yang hidup di masyarakat. Hukum yang hidup di dalam masyarakat biasa disebut dengan istilah the living law yang memiliki pengertian yaitu hukum yang hidup dan sedang aktual dalam suatu masyarakat, sehingga tidak membutuhkan upaya reaktualisasi lagi. The living law bukan sesuatu yang statis, tetapi terus berubah dari waktu ke waktu. The living law adalah hukum yang hidup di dalam masyarakat, bisa tertulis bisa juga tidak. ${ }^{11}$

Melihat penjelasan yang ada di atas terkait konsep yang ada di dalam pengaturan tindak pidana zina dalam KUHP, pada dasarnya memiliki beberapa masalah. Masalah yang ada dalam pengaturan tersebut antara lain karena masyarakat merasa unsur-unsur yang terdapat di dalam KUHP sudah tidak sesuai dengan nilai-nilai yang ada di dalam masyarakat Indonesia. Maka dari itu dalam hal ini penulis ingin melakukan kajian yang lebih dalam terkait dengan pengaturan tindak pidana zina tersebut dengan mengangkat judul Pengaturan Tindak Pidana Zina dalam Kitab Undang-Undang Hukum Pidana Dikaji Dari Perspektif Living Law.

\section{Rumusan Masalah}

Mengingat latar belakang permasalahan di atas, maka rumusan permasalahan dalam penelitian ini antara lain: Pertama, apakah Pasal 284 Kitab Undang-Undang Hukum Pidana masih relevan diterapkan pada tindak pidana zina bila dikaji dari perspektif living law? Kedua, bagaimana pengaturan tindak pidana zina yang relevan dalam pengaturan hukum di Indonesia?

${ }^{10}$ Indrawan Fajar Bin Zaufi Amri, M. Dachran S. Busthami, "Adultery in the Perspective of Islamic Law and the Criminal Law Legislation a Comparative Study" IOSR Journal of Humanities and Social Science (IOSR-JHSS) Volume 23, Issue 2, Ver. 1, 2018.

${ }^{11}$ Cut Asmaul Husna TR, "Penemnuan dan Pembentukan Hukum The Living Law' Melalui Putusan Hakim", Mizan Vol. 2 No. 3, Februari 2012, hlm. 70. 


\section{Tujuan Penelitian}

Dalam rencana penelitian ini, penulis bertujuan untuk mendapatkan hasil yakni: Pertama, untuk mengetahui relevan atau tidaknya pasal 284 Kitab UndangUndang Hukum Pidana diterapkan pada tindak pidana zina bila dikaji dari perspektif living law. Kedua, untuk mengetahui konsep tindak pidana zina yang relevan dalam pengaturan hukum di Indonesia.

\section{Metode Penelitian}

Pendekatan yang digunakan dalam penelitian ini adalah pendekatan sosio-legal dan pendekatan historis. Pendekatan sosio-legal, yaitu mendekati suatu permasalahan melalui penggabungan antara analisa normatif dengan pendekatan ilmu non-hukum dalam melihat hukum. Sedangkan pendekatan historis dilakukan dalam kerangka pelacakan sejarah lembaga hukum dari waktu ke waktu. Pendekatan ini sangat membantu peneliti untuk memahami filosofi hukum dari waktu ke waktu. Di samping itu, melalui pendekatan demikian peneliti juga dapat memahami perubahan dan perkembangan filosofi yang melandasi aturan hukum tersebut. ${ }^{12}$

\section{Hasil Penelitian dan Pembahasan}

\section{Tindak Pidana Zina dalam Kitab Undang-Undang Hukum Pidana}

Di dalam KUHP telah ditentukan larangan zina dan perzinaan dalam beberapa pasal yang dimuat dalam Buku II. Larangan zina pertama diatur di dalam Pasal 284 KUHP. Perbuatan zina atau mukah, menurut Pasal 284 KUHP adalah hubungan seksual atau persetubuhan di luar perkawinan yang dilakukan oleh seorang laki-laki dan seorang perempuan yang kedua-duanya atau salah satunya masih terikat dalam perkawinan dengan orang lain. Persetubuhan menurut R. Soesilo, ${ }^{13}$ adalah peraduan antara kemaluan laki-laki dan perempuan yang bisa dilakukan untuk mendapatkan anak. 126.

12 Peter Mahmud Marzuki, Penelitian Hukum, Cetakan Keempat, Prenada Media Group, Jakarta, 2008, hlm.

13 R. Soesilo, Kitab Undang-Undang Hukum Pidana (KUHP) Serta Komentarnya Lengkap Pasal Demi Pasal, Politeia, Bogor, 1980, hlm. 181. 
Ikatan perkawinan dititikberatkan dalam larangan zina sebab dalam Pasal 27 Burgelijk Wetboek diatur bahwa "dalam waktu yang sama seorang laki-laki hanya diperbolehkan mempunyai satu orang perempuan sebagai istrinya, seorang perempuan hanya satu orang laki-laki sebagai suaminya." Dengan demikian, sistem hukum Indonesia secara umum menganut asas monogami mutlak bagi warga negara yang agamanya mengimani hal tersebut, dan asas monogami terbuka bagi warga negara yang beragama Islam.

KUHP menentukan larangan hubungan seksual yang dapat dikategorikan sebagai tindak pidana zina yang dilakukan oleh orang yang masih terikat perkawinan, baik salah seorang pelaku zina atau kedua-duanya. Namun, KUHP juga memberikan ketentuan lain terhadap perbuatan yang dapat dikategorikan sebagai tindak pidana zina, seperti yang terdapat dalam Pasal 286 dan 287.

Menurut Neng Djubaedah, perbuatan pesretubuhan di luar perkawinan yang dapat dimasukkan sebagai perbuatan pidana adalah: ${ }^{14}$

1. Persetubuhan di luar perkawinan yang dilakukan oleh seorang laki-laki dan seorang perempuan yang kedua-duanya atau salah seorang pelakunya sedang dalam ikatan perkawinan yang sah dengan orang lain; atau

2. Persetubuhan di luar perkawinan yang dilakukan oleh seorang laki-laki terhadap perempuan yang dalam keadaan pingsan; atau

3. Persetubuhan di luar perkawinan yang dilakukan oleh seorang laki-laki terhadap perempuan yang dalam keadaan tidak berdaya; atau

4. Persetubuhan di luar perkawinan yang dilakukan oleh seorang laki-laki terhadap perempuan yang diketahuinya atau sepatutnya harus diduganya belum berumur 15 (lima belas) tahun; atau

5. Persetubuhan di luar perkawinan yang dilakukan oleh seorang laki-laki terhadap perempuan yang diketahuinya atau sepatutnya harus diduganya belum masanya untuk dikawini.

\section{Kajian Tindak Pidana Zina dalam Pasal 284 Kitab Undang-Undang Hukum Pidana dari Perspektif Living Law}

KUHP yang berlaku di Indonesia bersumber pada hukum Barat, maka tindak pidana zina yang diatur di Indonesia ialah menurut hukum Barat. Akan tetapi, kajian terhadap pengaturan tindak pidana zina dalam Pasal 284 KUHP dari perspektif living law dapat dilakukan dari beberapa bentuk hukum. Dalam hal ini 
kajian dari perspektif living law yang ada di Indonesia ialah melalui hukum Islam dan hukum adat. Perspektif dari hukum Islam maupun hukum adat akan mengkaji terkait dengan pengertian zina, pengaturan zina dan juga sanksi terhadap zina. Pengertian yang diuraikan dalam Pasal 284 KUHP, jika dilihat dari perspektif living law memiliki beberapa perbedaan. Apabila dilihat dari hukum Islam zina adalah hubungan seksual yang dilakukan oleh seorang laki-laki dengan seorang perempuan yang tidak terikat dalam perkawinan yang sah secara syariah Islam, atas dasar suka sama suka dari kedua belah pihak, atau dasar suka dari salah satu pihak (dalam kasus perkosaan) tanpa keraguan (syubhat) dari pelaku atau para pelaku zina bersangkutan. ${ }^{15}$

Menurut Ensiklopedia Hukum Islam, zina adalah, "hubungan seksual antara seorang laki-laki dengan seorang perempuan yang tidak atau belum diikat dalam perkawinan tanpa disertai unsur keraguan dalam hubungan seksual tersebut. ${ }^{16}$ Sedangkan menurut mazhab Hanafi, zina adalah hubungan seksual yang dilakukan seorang laki-laki secara sadar terhadap perempuan yang disertai nafsu seksual dan di antara mereka tidak atau belum ada ikatan perkawinan secara sah atau ikatan perkawinan syubhat, yaitu perkawinan yang diragukan keabsahannya, seperti ikatan perkawinan tanpa wali nikah, tanpa saksi, atau kawin mut'ah.17

Tindak pidana zina dalam Adat Minangkabau sama dengan delik yang dirumuskan oleh Agama Islam yaitu hubungan seksual antara pria dan wanita yang tidak terikat dengan perkawinan yang sah yang dilakukan secara sengaja. Sudah merupakan kelaziman bahwa setiap pelaku tindak pidana kesusilaan akan mendapatkan hukuman. Di Kenagarian Garagahan Lubuk Basung, misalnya, penerapan sanksi adat terhadap pelaku tindak pidana zina, khususnya yaitu berupa denda 5 karung semen; dikucilkan dari masyarakat; diusir dari kampung dan denda kepada mamak adat berupa keris, deta, saluak dan emas. Namun penerapan sanksi ini belum berjalan sebagaimana mestinya karena banyaknya

\footnotetext{
${ }^{15}$ Neng Djubaedah, Perzinaan dalam ... Op. Cit., hlm. 182.

16 Abdul Aziz Dahlan, Ensiklopedia Hukum Islam, jilid 6, Cetakan Pertama (Jakarta: Ichtiar Baru van Hoeve, 1996), hlm. 2026.

${ }_{17}$ Neng Djubaedah, Perzinaan: Dalam Peraturan Perundang-undangan di Indonesia Ditinjau dari Hukum Islam, Kencana, Jakarta, 2010, hlm. 182-183.
} 
pertimbangan-pertimbangan sosial oleh kepala adat dalam mengambil keputusan serta banyaknya perbuatan zina yang tidak dilaporkan.

Di masyarakat adat Tolaki, sanksi yang diterapkan terhadap pelaku tindak pidana kesusilaan terbagi menjadi 2 yaitu peohala dan pinakawi. Sanksi peohala yaitu pemberian ganti kerugian berupa uang, sarung dan kain kafan beserta isi-isi adat lainnya yang diberikan kepada pelaku tindak pidana kesusilaan ringan seperti pencabulan, pelecehan seksual. Sanksi pinakawi yaitu pernikahan yang dilakukan karena adanya pelanggaran adat yang dianggap melanggar norma-norma hukum adat dan hukum Islam yang diberikan kepada pelaku tindak pidana seksual berat seperti tindak pidana pemerkosaan, dan perzinaan.

Pengertian zina menurut Pasal 284 KUHP yang diisyaratkan harus laki-laki atau perempuan yang sedang kawin, berlatar belakang pada pemikiran Belanda bahwa zina adalah pengingkaran perkawinan, yang berbeda menurut hukum adat yang berlatar belakang penodaan nilai-nilai kesucian daripada persetubuhan. Menurut hukum adat di dalam persetubuhan itu terkandung nilai-nilai kesucian. Oleh karena itu, untuk melakukannya diperlukan syarat, yaitu perkawinan. Apabila dilakukan di luar perkawinan, dia berdosa dan telah melanggar nilai kesucian itu, dia berzina, oleh sebab itu si pembuatnya harus dihukum. ${ }^{18}$

Pengakuan atas hukum adat tertuang di berbagai peraturan perundangan, sehingga ini membuktikan bahwa eksistensi keberadaan hukum adat dalam hukum positif masih tetap dipertahankan meskipun ada beberapa hal tertentu hukum adat di batasi kewenangannya. Olehnya itu, kekosongan dalam hukum tertulis tidak harus dijadikan alasan hukum untuk tidak mengualifikasikan perbuatan perzinaan tersebut ke dalam perbuatan melawan hukum. Sebab, apapun alasannya perbuatan zina tersebut merupakan pelanggaran oleh aturan-aturan hukum tidak tertulis merupakan salah satu aturan yang diakui hidup pada masyarakat Indonesia sebagaimana telah disebutkan dalam ketentuan Pasal 5 ayat (3) sub b Undang-Undang Darurat Nomor 1 Tahun 1951 tentang Pemberlakuan Hukum Pidana Adat. Fleksibilitas seperti ini, diharapkan agar hukum agar benarbenar dapat digunakan sebagai instrumen untuk menciptakan keadilan di satu sisi

${ }^{18}$ Ledeng Marpaung, Kejahatan terbadap Kesusilaan dan Masalab Prevensinya, Sinar Grafika, Jakarta, 2004, hlm. 
(kebenaran riil), dan tidak mengenyampingkan kepastian hukum di sisi lain (kebenaran formiil), terlebih dalam hukum positif Indonesia mengakui bahwa salah satu sumber hukum formiil adalah hukum adat.

\section{Analisis Atas Implementasi Penegakan Tindak Pidana Zina Sebagai Bagian dari Kebijakan Hukum Pidana}

Membahas tentang efektivitas hukum maka tidak terlepas dari penegakan hukum. Hukum dapat dikatakan efektif jika terdapat dampak hukum yang positif, hukum mencapai sasarannya dalam membimbing perilaku manusia sehingga menjadi perilaku hukum. Soerjono Soekanto mengemukakan lima faktor yang harus diperhatikan dalam penegakan hukum. Kelima faktor itu meliputi: ${ }^{19}$ a. faktor hukum atau undang-undang; b. faktor penegak hukum; c. faktor sarana atau fasilitas; d. faktor masyarakat; dan e. faktor kebudayaan.

Ditinjau dari faktor hukum atau Undang-Undang, dapat dikatakan bahwa hukum atau Undang-Undang dalam arti materiil merupakan peraturan tertulis yang berlaku umum dan dibuat oleh penguasa pusat maupun daerah yang sah. Peraturan dibagi dua macam, yaitu peraturan pusat dan peraturan setempat. Peraturan pusat berlaku untuk semua warga negara atau suatu golongan tertentu saja maupun yang berlaku umum di sebagian wilayah negara. Peraturan setempat hanya berlaku di suatu tempat atau daerah saja. ${ }^{20}$ Peraturan terkait dengan tindak pidana zina di Indonesia merupakan peraturan pusat yang dapat ditemukan dalam Pasal 284 KUHP.

Pasal 284 KUHP memberikan celah bagi masyarakat yang belum kawin untuk dapat melakukan perbuatan zina. Dengan kata lain, pria atau wanita yang belum kawin tidak menjadi cakupan dalam peraturan ini, sehingga efek yang timbul adalah banyak terjadinya pergaulan bebas atau hubungan seksual yang dilakukan oleh masyarakat yang belum kawin. Di sisi lain, pasal ini juga merupakan delik aduan, tindak pidana zina hanya akan dilakukan penuntutan apabila adanya pengaduan.

\footnotetext{
${ }^{19}$ Soerjono Soekanto, Faktor-Faktor yang Mempengarubi Penegakan Hukum, Cetakan Ketiga Belas, Rajawali Pers, Jakarta, 2014, hlm. 8.

${ }^{20}$ Salim HS dan Erlies Septiana Nurbani, Penerapan Teori Hukum Pada Penelitian Tesis dan Disertasi, Cetakan Kelima, RajaGrafindo Persada, Jakarta, 2017, hlm. 307.
} 
Ditinjau dari faktor penegak hukum, penegakan hukum yang dilakukan oleh penegak hukum di Indonesia terkait dengan perbuatan tindak pidana zina selama ini masih menerapkan Pasal 284 KUHP, yaitu dengan menunggu adanya aduan dari pihak yang mempunyai kewenangan. Walaupun terkadang penegak hukum juga melakukan razia terhadap lokasi remang-remang yang di mana biasa terjadi hubungan seksual yang dilakukan oleh pasangan yang tidak sah. Namun dalam penegakannya tidak diterapkan Pasal 284 KUHP, karena salah satu unsur dari pasal tersebut harus ada aduan dari suami atau istri.

Ditinjau dari faktor sarana atau fasilitas, sarana atau fasilitas itu sendiri meliputi tenaga manusia yang berpendidikan dan terampil, organisasi yang baik, peralatan yang memadai, keuangan yang cukup, dan sebagainya. Kalau hal itu tidak dipenuhi, maka mustahil penegakan hukum akan mencapai tujuannya.. ${ }^{21}$ Pada dasarnya sarana atau fasilitas yang dibutuhkan telah tersedia, tetapi kembali kepada unsur pasal perzinaan yang mengharuskan adanya aduan dari suami atau istri yang tercemar. Sehingga sarana atau fasilitas yang sudah ada tidak dapat dimanfaatkan sebelum adanya aduan tersebut.

Ditinjau dari faktor masyarakat, masyarakat Indonesia dalam menyikapi perbuatan zina terkadang tidak sesuai dengan aturan yang terdapat dalam Pasal 284 KUHP. Hal ini dapat dilihat ketika terjadi tindakan main hakim sendiri yang dilakukan oleh masyarakat terhadap pelaku perbuatan zina. Seperti pemberitaan yang ada di dalam media online yang menyatakan "Sepanjang 2017, catatan penangkapan, penggerebekan, dan persekusi warga karena urusan seksualitasnya bertambah panjang. Bagi sebagian masyarakat, seks adalah untuk mereka yang heteroseksual dan telah menikah saja".22 Faktor-faktor tersebut harus diperhatikan secara saksama dalam proses penegakan hukum, karena apabila hal itu kurang mendapat perhatian maka penegakan hukum tidak akan tercapai. ${ }^{23}$

Pengaturan tindak pidana zina di dalam Pasal 284 KUHP masih menjadi pro dan kontra di masyarakat. Indonesia merupakan negara dengan pemeluk agama Islam terbesar di dunia, sehingga nilai-nilai Islam turut mewarnai kebudayaan

\footnotetext{
${ }^{21}$ Soerjono Soekanto, Fak.tor-Faktor... Op. Cit.

22 "Masyarakat AMP Negara Masih Gatal Urusi Seksualitas Individu", https://tirto.id/2017-masyarakatamp-negara-masih-gatal-urusi-seksualitas-individu-cCw7, diakses pada tanggal 6 November 2018.

${ }^{23}$ Salim HS dan Erlies Septiana Nurbani, Penerapan Teori ...Op. Cit., hlm. 308.
} 
masyarakat Indonesia. Dalam konteks Islam, merupakan dosa besar apabila melakukan hubungan seksual antara pasangan yang tidak sah. Di samping itu, nilai-nilai adat yang ada di dalam masyarakat Indonesia juga mengajarkan bahwa apabila terjadi hubungan seksual yang dilakukan oleh pasangan yang tidak terikat di dalam perkawinan yang sah, maka dinyatakan telah melanggar aturan adat. Pada dasarnya dapat dikatakan bahwa nilai yang ada di dalam masyarakat terkait dengan perbuatan zina tidak hanya pria atau wanita yang sudah kawin tetapi bagi yang belum kawin juga dikatakan melakukan perbuatan zina. Hal ini dapat kita lihat di dalam peraturan-peraturan adat yang ada di Indonesia, seperti Lokika Sanggraha sebagaimana dirumuskan di dalam Kitab Adi Agama Pasal 359 serta perkembangan pandangan masyarakat dan praktik peradilan di daerah Bali adalah hubungan cinta antara seorang pria dengan seorang wanita yang sama-sama belum terikat perkawinan, dilanjutkan dengan hubungan seksual atas dasar suka sama suka karena adanya janji dari si pria untuk mengawini si wanita, namun setelah si wanita hamil si pria memungkiri janji untuk mengawininya dan memutuskan hubungan cintanya tanpa alasan yang sah. ${ }^{24}$

Dari hasil peninjauan berbagai faktor di atas, Penulis berkesimpulan bahwa implementasi Pasal 284 KUHP terhadap penanggulangan perbuatan tindak pidana zina selama ini belum dapat terimplementasi dengan efektif. Sebagaimana yang telah Penulis paparkan di atas, ada banyak ketidaksesuaian antara peraturan perundang-undangan yang telah ditetapkan dengan implementasi kenyataannya di masyarakat.

\section{Pembaharuan Konsep Tindak Pidana Zina di Indonesia}

Pada dasarnya pembaruan hukum pidana (penal reform) merupakan bagian dari politik hukum pidana (penal policy). Makna dan hakikat pembaruan hukum pidana berkaitan erat dengan latar belakang dan urgensi diadakannya pembaruan hukum pidana itu sendiri. Latar belakang dan urgensi diadakannya pembaruan hukum pidana dapat ditinjau dari aspek sosio-politik, sosio-filosofis, sosio-kultural

${ }^{24}$ I Dewa Made Suartha, Hukum dan Sanksi Adat Perspektif Pembabaruan Hukum Pidana, Setara Press, Malang, 2015, hlm. 122-123. 
atau dari berbagai aspek kebijakan (khususnya kebijakan sosial, kebijakan kriminal, dan kebijakan penegakan hukum). Artinya, pembaruan hukum pidana juga pada hakikatnya harus merupakan perwujudan dari perubahan dan pembaruan terhadap berbagai aspek dan kebijakan yang melatarbelakanginya itu. Dengan demikian, pembaruan hukum pidana pada hakikatnya mengandung makna, suatu upaya untuk melakukan reorientasi dan reformasi hukum pidana yang sesuai dengan nilai-nilai tersebut di atas. Secara singkat dapat dikatakan bahwa pembaruan hukum pidana pada hakikatnya harus ditempuh dengan pendekatan yang berorientasi pada kebijakan ("policy-oriented approach") dan sekaligus pendekatan yang beroreintasi pada nilai ("value-oriented approach"). ${ }^{25}$

Pembaharuan hukum pidana dapat dilakukan dengan cara merevisi, memperbaiki, menambah, mengurangi, melengkapi ketentuan hukum yang sudah ada atau membuat sesuatu yang baru. Tampaknya dalam sejarahnya, maka kedua cara inilah yang terjadi di Indonesia. ${ }^{26}$

Urgensi perubahan terhadap KUHP didasarkan kepada pertimbangan politis, praktis dan sosiologis. ${ }^{27}$ Alasan politis, yakni sebagai negara yang merdeka, wajar bahwa Negara Republik Indonesia memiliki KUHP yang bersifat nasional. Tugas pembentuk undang-undang untuk menasionalisasikan semua perundangundangan warisan zaman kolonial dan usaha tersebut harus didasarkan kepada Pancasila sebagai sumber dari segala sumber hukum.

Alasan praktis didasarkan kenyataan semakin sedikitnya sarjana hukum Indonesia yang mampu memahami bahasa Belanda berikut asas-asas hukumnya. Alasan sosiologis di mana KUHP berisi pencerminan dari nilai-nilai kebudayaan dari suatu bangsa. WvS belum sesuai dengan kebutuhan masyarakat.

\section{Konsep Tindak Pidana Zina yang Relevan dalam Pengaturan Hukum di Indonesia}

Hukum tidak akan mungkin bekerja dalam ruang hampa. Itulah sebabnya hukum dalam realitasnya berfungsi sebagai faktor pengintegrasian masyarakat.

\footnotetext{
${ }^{25}$ Ibid., hlm. 28-29.

${ }^{26}$ Muhammad Taufik Makarao, Pembaharuan Hukum Pidana Indonesia StudiTentang Bentuk-Bentuk Pidana Khususnya Pidana Cambuk Sebagai Suatu Bentuk Pemidanaan, Cetakan Pertama, Kreasi Wacana, Yogyakarta, 2005, hlm. 19.

${ }^{27}$ Soedarto, Hukum dan Hukum Pidana, Penerbit Alumni, Bandung, 1981, hlm. 70-71.
} 
Sebagai pengatur sosial, hukum harus menjalani suatu proses yang panjang dan melibatkan berbagai aktivitas dengan kualitas yang berbeda-beda dalam proses pembuatan hukum dan proses implementasi hukum. Proses pembuatan hukum itu sesungguhnya mengandung pengertian yang sama dengan istilah proses pembuatan UU.

Pembuatan hukum merupakan awal dari bergulirnya proses pengaturan pola pembentukan hukum untuk mengatur tatanan kehidupan sosial. Dalam masyarakat demokratis yang modern, badan legislatif berdaulat dalam membuat kebijakan pembuatan hukum untuk menyalurkan aspirasi masyarakat. Pada prinsipnya proses pembuatan hukum tersebut berlangsung dalam tiga tahapan besar, yakni :28

(1)Tahap Inisiasi Lahirnya gagasan dalam masyarakat perlunya pengaturan suatu hal melalui hukum yang masih murni merupakan aktivitas sosiologis. Sebagai bentuk reaksi terhadap sebuah fenomena sosial yang diprediksikan dapat mengganggu keteraturan dan ketertiban dalam kehidupan bermasyarakat, berbangsa, dan bernegara. Di sinilah letak betapa pentingnya kajian-kajian sosiologis dalam memberikan sumbangan informasi yang memadai untuk memperkuat gagasan tentang perlunya pengaturan sesuatu hal dalam tatanan hukum.

(2)Tahap Sosio-Politis \& Tahap Yuridis

Sosio-politis ini dimulai dengan mengolah, membicarakan, mengkritisi, mempertahankan gagasan awal masyarakat melalui pertukaran pendapat berbagai golongan dan kekuatan dalam masyarakat. Gagasan akan mengalami ujian, apakah ia bisa terus berjalan untuk berproses menjadi sebuah produk hukum atau berhenti di tengah jalan. Apabila gagasan tersebut gagal dalam ujian dengan sendirinya akan hilang dan tidak dipermasalahkan di dalam masyarakat. Apabila gagasan tersebut berhasil untuk dijalankan terus, maka format dan substansinya mengalami perubahan yang menjadikan bentuk dan isi gagasan tersebut semakin luas dan dipertajam.

(3) Tahap Penyebarluasan

Gagasan dirumuskan lebih lanjut secara lebih teknis menjadi hukum, termasuk menetapkan saksi hukumnya yang melibatkan kegiatan intelektual yang bersifat murni dan tidak terlibat konflik kepentingan (conflict of interest) politik, yang tentunya ditangani oleh tenaga-tenaga yang khusus berpendidikan hukum. Merumuskan bahan hukum menurut bahasa hukum dan memeriksa meneliti konteks sistem hukum yang ada sehingga tidak menimbulkan

28 http:/ / zriefmaronie.blogspot.com/2014/05/bekerjanya-hukum-dalam-masyarakat.html 
gangguan sebagai satu kesatuan sistem. Tahap terakhir adalah tahap penyebarluasan yang menjadi tahap sosialisasi produk hukum. Sosialisasi ini berpengaruh terhadap bekerjanya hukum di masyarakat. Sebagus apa pun substansial hukum jika tidak disosialisasikan dengan baik, maka hukum tersebut tidak dapat diterapkan dengan baik di masyarakat.

Pembuatan hukum di sini hanya merupakan pencerminan dari nilai-nilai yang disepakati dan dipertahankan oleh warga masyarakat. Langkah pembuatan hukum dimungkinkan adanya konflik-konflik atau tegangan secara internal. Di mana nilai-nilai dan kepentingan-kepentingan yang bertentangan dapat tanpa mengganggu kehidupan masyarakat. Padahal pembuatan hukum memiliki arti yang sangat penting dalam mengubah perilaku warga masyarakat. Hukum baru memiliki makna setelah ditegakkan karena tanpa penegakan hukum bukan apaapa. Namun ketika bertentangan dengan keadaan dimasyarakat maka akan sia-sia juga kelahiran hukum tersebut.

Konsep pengaturan tindak pidana zina di Indonesia memang sudah seharusnya dilakukan perubahan, karena melihat aturan yang ada yaitu dalam Pasal 284 KUHP sudah tidak relevan lagi untuk diterapkan kepada masyarakat. Selain itu perbuatan zina di mata masyarakat merupakan perbuatan yang sangat tercela dan merugikan berbagai pihak terutama terkait dengan keturunan. Senada dengan pernyataan Bapak Mudzakkir, yaitu bahwa dalam perkara zina yang menjadi masalah pada hubungannya tetapi titik fokus permasalahannya terdapat pada anak yang lahir karena perzinaan yang mana anak tersebut akan menanggung sosial kemanusiaan. Selain itu zina juga melanggar dasar Ketuhanan Yang Maha Esa, karena melakukan perbuatan manusiawi atau kemanusiaan dengan cara yang terlarang, karena dalam perkara zina telah melanggar prinsip nilai yaitu nilai hubungan seksual yang harus dilakukan dengan adanya ikatan yang sah. ${ }^{29}$

Dalam pembentukan konsep tersebut maka harus dilakukan berbagai pertimbangan dan melihat kondisi masyarakat yang ada. Pengaturan tindak pidana zina yang relevan pada dasarnya dapat kita lihat dari hasil wawancara yang sudah dilakukan terhadap beberapa narasumber, yaitu:

${ }^{29}$ Hasil wawancara dengan Bapak Dr. Mudzakkir, S.H., M.H. Dosen Fakultas Hukum Universitas Islam Indonesia, pada tanggal 7 Februari 2019. 
1. Ibu Husnul Khotimah selaku Ketua PN Wonosari30

Menurut beliau pengaturan tindak pidana zina yang ada pada saat ini merupakan produk dari Belanda, karena KUHP yang ada merupakan peninggalan dari Belanda dan sejarah yang melatarbelakangi KUHP tersebut tidak sesuai dengan konteks yang ada di Indonesia. Sehingga aturan terkait dengan tindak pidana zina sangat tidak sesuai dengan nilainilai yang ada di dalam masyarakat Indonesia. Maka dalam pengaturan tindak pidana zina harus mengembalikan pengertian zina tersebut, yaitu hubungan suami istri yang dilakukan tanpa adanya ikatan (lisensi). Selain itu juga harus diperhatikan bahwa masyarakat Indonesia merupakan masyarakat yang beragama dan semua agama yang ada di Indonesia tidak ada yang membolehkan atau mengesahkan perbuatan zina, maka masyarakat Indonesia juga menyerap bahwa zina merupakan hal yang tidak boleh dilakukan. Kemudian beliau juga mengungkapkan bahwa dalam perkara zina terkait dengan adanya aduan harus tetap ada, karena dalam perkara zina pada dasarnya merupakan perkara hati, sehingga adanya aduan dijadikan sebagai unsur kehati-hatian. Hal tersebut dalam rangka menjaga moral atau status sosial, terutama bagi kehidupan berumah tangga dan juga keluarganya.

2. Bapak Mudzakkir selaku ahli Hukum Pidana dan Akademisi Hukum Pidana $^{31}$

Menurut beliau pengaturan zina yang masuk dalam Hukum Pidana adalah hubungan seksual yang terlarang. Hal ini dikarenakan zina dapat merusak hubungan keluarga yang terdapat dalam filsafat hubungan seksual. Sehingga dalam pengaturan zina harus memberikan aturan terkait dengan segala perbuatan hubungan seksual yang dapat merusak hubungan keluarga (Hukum Perkawinan), termasuk juga merusak nashab (silsilah keluarga). Jadi dalam membuat aturan terkait dengan perbuatan zina harus memperhatikan konsep atau filsafat hubungan seksual dan Hukum Perkawinan, yaitu bahwa hubungan seksual harus dilakukan dengan adanya ikatan yang sah. Di sisi lain beliau mengungkapkan terkait dengan adanya aduan dalam perkara zina harus dilihat dari konsep yang digunakan, yaitu konsep publik atau privat. Perkara zina pada dasarnya yang dilanggar adalah nilai, sehingga tidak bisa dikategorikan dalam ranah privat atau publik. Melainkan nilai-nilai Pancasila adalah sumber dari segala sumber dalam membentuk hukum negara, sehingga ketika melanggar nilai maka telah melanggar hukum negara. Maka dalam membuktikan perkara zina adalah suatu bagian dari hukum negara, maka dari itu zina menjadi hukum publik karena telah melanggar nilai-nilai, jadi tidak pantas untuk dijadikan sebagai delik aduan.

\footnotetext{
${ }^{30}$ Hasil wawancara dengan Ibu Husnul Khotimah Ketua PN Wonosari, pada tanggal 21 Januari 2019.

31 Hasil wawancara dengan Bapak Dr. Mudzakkir, S.H., M.H. Dosen Fakultas Hukum Universitas Islam Indonesia, pada tanggal 7 Februari 2019.
} 
3. Bapak Yunahar Ilyas selaku Ketua MUI ${ }^{32}$

Menurut beliau pengaturan tindak pidana zina yang relevan di Indonesia adalah aturan yang berasal dari nilai-nilai masyarakat dan melihat kondisi masyarakat Indonesia. Maka dari itu harus melihat bagaimana pengertian zina yang ada di dalam masyarakat, karena pandangan yang ada di masyarakat saat ini sangat berbeda dengan pengertian tindak pidana yang ada di dalam Pasal 284 KUHP. Beliau menambahkan tidak setuju terkait tindak pidana zina sebagai delik aduan, tetapi di dalam pembuktiannya harus dibuat secara jelas agar tidak terjadi fitnah, karena di dalam ajaran agama Islam memfitnah orang berbuat zina merupakan perbuatan dosa besar. Di sisi lain Prof. Yunahar juga menjelaskan bahwa selama ini Majelis Ulama Indonesia (MUI) telah memberikan masukan secara langsung kepada Dewan Perwakilan Rakyat Republik Indonesia (DPR RI) melalui Bambang Sutiyoso terkait dengan pengaturan zina. Dalam penyampaian yang dilakukan oleh MUI terkait dengan pengaturan zina adalah terfokus kepada unsur-unsur yang ada, seharusnya unsur-unsur yang ada di dalam tindak pidana zina dikembalikan kepada pengertian zina yaitu hubungan yang dilakukan oleh pasangan yang tidak ada ikatan atau pasangan yang tidak sah.

Melihat penjelasan yang ada di atas, maka dapat ditarik kesimpulan bahwa pengaturan zina yang relevan di Indonesia adalah mengembalikan pengertian zina kepada arti sebenarnya, yaitu hubungan seksual yang dilakukan oleh pasangan yang tidak sah. Sehingga dalam unsur tindak pidana zina tidak hanya dibatasi hubungan yang dilakukan oleh pria atau wanita yang salah satunya terikat dengan perkawinan. Selain itu, tindak pidana zina seharusnya tidak menjadi delik aduan, karena perbuatan zina telah melanggar nilai-nilai yang ada di dalam masyarakat terutama nilai Ketuhanan Yang Maha Esa. Namun dalam pembuktian tindak pidana zina harus diatur dengan jelas, agar tidak terjadi fitnah dan kerancuan.

\section{Penutup}

Berdasarkan uraian pembahasan atas permasalahan yang diangkat dalam penelitian ini, maka terdapat beberapa hal pokok yang dapat dijadikan sebagai kesimpulan, yaitu sebagai berikut : pertama, Pasal 284 KUHP sudah tidak relevan lagi diterapkan terhadap perbuatan zina yang ada di dalam masyarakat Indonesia. Pasal yang sudah dikatakan tidak relevan berarti pasal tersebut juga sudah tidak

32 Hasil wawancara dengan Bapak Prof. Dr. Yunahar Ilyas, Lc., M.Ag. Ketua Majelis Ulama Indonesia Pusat, pada tanggal 21 Februari 2019. 
efektif lagi untuk diterapkan, maka Pasal 284 KUHP dapat dikatakan sebagai pasal yang sudah tidak efektif untuk diterapkan dalam masyarakat. Hal tersebut dibuktikan dengan ada banyak temuan ketidaksesuaian antara regulasi yang telah ditetapkan dengan implementasi kenyataannya di dalam masyarakat; yang ditinjau dari faktor hukum atau undang-undang, faktor penegak hukum, faktor sarana atau fasilitas, faktor masyarakat, dan faktor kebudayaan. Selain itu, ketidaksesuaian tersebut ditegaskan bahwa pasal tersebut tidak sesuai dengan nilanilai yang ada di dalam masyarakat Indonesia, karena konsep zina yang ada di dalam Pasal 284 KUHP tidak sesuai dengan konsep zina yang ada di dalam masyarakat. Melihat hal tersebut maka harus diyakini bahwa hukum yang relevan adalah hukum yang sesuai dengan nilai-nilai masyarakat dan hukum harus diposisikan untuk manusia bukan manusia untuk hukum. Kedua, pengaturan terhadap tindak pidana zina yang relevan di Indonesia adalah mengembalikan pengertian zina kepada arti sebenarnya, yaitu hubungan seksual yang dilakukan oleh pasangan yang tidak sah. Sehingga dalam unsur tindak pidana zina tidak hanya dibatasi hubungan yang dilakukan oleh pria atau wanita yang salah satunya terikat dengan perkawinan. Selain itu, tindak pidana zina seharusnya tidak menjadi delik aduan, karena perbuatan zina telah melanggar nilai-nilai yang ada di dalam masyarakat terutama nilai Ketuhanan Yang Maha Esa, maka setiap perbuatan yang telah melanggar nilai-nilai masyarakat dapat dijadikan sebagai delik biasa. Namun dalam pembuktian unsur-unsur peraturan terkait dengan tindak pidana zina harus memiliki aturan yang jelas dan tegas, agar tidak terjadi fitnah dan kerancuan dalam penegakan hukum.

Berdasarkan uraian pembahasan atas permasalahan yang diangkat dalam penelitian Tesis ini, maka terdapat beberapa hal pokok yang dapat dijadikan sebagai saran, yaitu sebagai berikut : pertama, pemerintah harus melakukan kajian secara komprehensif terhadap Pasal 284 KUHP terkait dengan tindak pidana zina agar dapat diterapkan secara efektif. Selain itu, pemerintah juga dapat segera memperbaharui Kitab Undang-Undang Hukum Pidana yang diterapkan di Indonesia dan di dalamnya mengatur perbuatan zina yang efektif. Hal tersebut harus dilakukan agar perbuatan zina yang sudah merajalela di dalam pergaulan 
masyarakat bisa dihilangkan, karena perbuatan zina dapat merusak moral para generasi bangsa dan juga dapat merusak keturunan. Mengingat bahwa negara Indonesia merupakan negara hukum, sehingga setiap perbuatan harus diatur menggunakan hukum yang berlaku. Kedua, perbuatan zina di Indonesia seharusnya diatur dengan peraturan yang diambil dari nilai-nilai yang ada di dalam masyarakat. Hal ini harus dilakukan karena perbuatan zina merupakan perbuatan yang sudah dianggap sangat tercela. Selain itu pengertian dan unsur-unsur yang terdapat dalam aturan zina juga harus dikembalikan kepada pengertian dan unsur-unsur zina yang sesungguhnya, agar peraturan tersebut dapat relevan dengan masyarakat Indonesia yang berdasarkan Pancasila. Maka dari itu pembaharuan terhadap Kitab UndangUndang Hukum Pidana harus segera dilakukan dan disesuaikan dengan nilai-nilai yang ada di dalam masyarakat.

\section{Daftar Pustaka}

\section{Buku}

Almaududi, Abdul A’la, Kejamkah Hukum Islam, Gema Insani Press, Jakarta, 1979.

An-Nasaburi, Imam Abi Husein Muslim bin Hajjaj Al-Qusaery, Shahih Muslim Juz II, Dar Kitab Al-Ilmiyah, Beirut.

Bushar, Muhammad, Asas-Asas Hukum Adat Suatu Pengantar, Pradnya Paramita, Jakarta, 2006.

Dahlan, Abdul Aziz, Ensiklopedia Hukum Islam, jilid 6, Cetakan Pertama, Ichtiar Baru van Hoeve, Jakarta, 1996.

Djubaedah, Neng, Perzinaan Dalam Peraturan Perundang-Undangan Di Indonesia Ditinjau Dari Hukum Islam, Cetakan Pertama, Kencana Pernada Media Group, Jakarta, 2010.

Hamzah, Andi, KUHP dan KUHAP, Cetakan Kedua, Rineka Cipta, Jakarta, 1992.

Hatubi, Abd. Latif Parase, Isi Lokakarya Unifikasi Hukum Adat Sarano Tolaki, Kendari, 2006.

H.S., Salim dan Erlies Septiana Nurbani, Penerapan Teori Hukum Pada Penelitian Tesis dan Disertasi, Cetakan Kelima, RajaGrafindo Persada, Jakarta, 2017.

Makarao, Muhammad Taufik, Pembaharuan Hukum Pidana Indonesia StudiTentang Bentuk-Bentuk Pidana Khususnya Pidana Cambuk Sebagai Suatu Bentuk Pemidanaan, Cetakan Pertama, Kreasi Wacana, Yogyakarta, 2005.

Marpaung, Ledeng, Kejahatan terhadap Kesusilaan dan Masalah Prevensinya, Sinar Grafika, Jakarta, 2004. 
Marzuki, Peter Mahmud, Penelitian Hukum, Cetakan Keempat, Prenada Media Group, Jakarta, 2008.

Moeljatno, KUHP Kitab Undang-Undang Hukum Pidana, Cetakan Keduapuluh Tujuh, Bumi Aksara, Jakarta, 2008.

Mudzakkir, Sistem Hukum Indonesia Menurut H. Moh. Koesnoe, Jakarta, 1997.

Prodjodikoro, Wirjono, Asas-asas Hukum Pidana di Indonesia, Cetakan Ketiga, Eresco, Jakarta, 1981.

Rosdalina, Hukum Adat, Cetakan Pertama, Deepublish, Yogyakarta, 2017.

Santoso, Topo, Membumikan Hukum Pidana Islam: Penegakan Syariat dalam Wacana dan Agenda, Cetakan Pertama, Gema Insani Press, Jakarta, 2003.

Soedarto, Hukum dan Hukum Pidana, Penerbit Alumni, Bandung, 1981.

Soekanto, Soerjono, Faktor-faktor yang mempengaruhi Penegakan Hukum, Cetakan Ketiga Belas, Rajawali Pers, Jakarta, 2014.

Soesilo, R., Kitab Undang-Undang Hukum Pidana (KUHP) Serta Komentar Komentarnya Lengkap Pasal Demi Pasal, Politeia, Bogor, 1980.

Suartha, I Dewa Made, Hukum dan Sanksi Adat Perspektif Pembaharuan Hukum Pidana, Setara Press, Malang, 2015.

Sulaeman, Erman, Delik Perzinaan Dalam Pembaharuan Hukum Pidana di Indonesia, Semarang: Walisongo Press, Semarang, 2008.

van Bemmelen, J. M., Hukum Pidana 3, Bagian Khusus Delik-Delik Khusus, Cetakan Pertama, Binacipta, Bandung, 1986.

\section{Jurnal}

Indrawan Fajar Bin Zaufi Amri, M. Dachran S. Busthami, "Adultery in the Perspective of Islamic Law and the Criminal Law Legislation a Comparative Study" IOSR Journal of Humanities and Social Science (IOSRJHSS) Volume 23, Issue 2, Ver. 1, 2018.

\section{Majalah}

Cut Asmaul Husna TR, "Penemuan dan Pembentukan Hukum 'The Living Law' Melalui Putusan Hakim", Mizan VOL 2 No. 3, Februari 2012.

\section{Internet}

"Bekerjanya Hukum dalam Masyarakat", http://zriefmaronie.blogspot.com/ 2014/05/bekerjanya-hukum-dalam-masyarakat.html, diakses tanggal 24 Februari 2019.

"Masyarakat AMP Negara Masih Gatal Urusi Seksualitas Individu", https: / / tirto.id/2017-masyarakat-amp-negara-masih-gatal-urusiseksualitas-individu-cCw7, diakses tanggal 6 November 2018. 